\title{
Constitutionalism and Cultural Identity as revolutionary concepts in German political radicalism 1806-1819: the case of the Burschenschaftler Karl Follen
}

\section{Maike Oergel}

The aim of this essay is to investigate the concepts of cultural identity and national sovereignty as they emerge in radical German nationalism after 1806 in relation to French Revolutionary ideas and seek to reconstruct a radical revolutionary, i.e. a 'French Revolution', context for the idea of German national unity. Such a 'French Revolution' context differs from attempts to create national unity 'from above', it also questions the view that the 'Teutomania' emerging in the context of the Wars of Liberation can only be interpreted as the precursor to chauvinist German nationalism of later periods.

The investigation will focus on a specific example: the political ideas, and militancy, of Burschenschaftler Karl Follen (1796-1840) as they found expression in his conception of student organisations, the outline of the all-German constitution he co-authored with this brother August, and his martial poetry. The investigation delineates the overlap between the French republican (Montagnard) constitution of June 1793and the Follen outline, as well as the differences between the two. It asks whether these differences may be due to the German need for imaginative nationbuilding under conditions perceived as cultural and political oppression. The idea that the differences between the two constitutions, which in the main relate to a greater focus on cultural specificity in the German constitution, could be due to an acute sense of oppression rather than superiority, is based on the pronounced similarity between Follen's approach to national liberation and that of Frantz Fanon over a century later. Both Follen and Fanon insist that an historically developed cultural identity and uncompromising militancy are necessary for national liberation, i.e. for a liberation of the people, to succeed.

In Germany, as in many places in Europe, the French Revolution gave a new intensity to debates about appropriate and just forms of government. Over its course the Revolution, and the succeeding Napoleonic period, produced a continuum of political responses, from radical politics via reformist (moderate) politics to reactionary politics. A distinct phase of public, private, and secret debates about the future political shape of Germany began after Napoleon's defeat of Prussia in 1806, which marked the beginning of Napoleon's hegemony in Europe. The contributions to these debates engage with concepts of 'nation' and 'state' and range from Fichte's impassioned public lectures in 1807-08 calling for a national education programme to protect German, and human as he saw it, cultural and spiritual achievements, to Friedrich Ludwig Jahn's and Karl Friedrich Friesen's secret outline for an Ordnung und Einrichtung des deutschen Burschenwesens (1811), ${ }^{1}$ a plan to organise university students into a political and eventually military national opposition against French occupation and political control from (newly) Imperial France. Jahn extended this mobilisation beyond university students to a wider social mix of young men through his gymnastics movement, the Turnbewegung, which started its public activities in June 1811 and was intended to further moral and physical education as well as contribute to paramilitary training for national liberation. These activities paved the way for a well organised levée en masse against Napoleon's forces, which contributed to the success of the Wars of Liberation 1813-14. The reorganisation of student associations and the setting up of the Turnbewegung was largely a call to arms to liberate the German territories from the 'Franzonenherrschaft' (rule of the French). Crucially in this context, it

\footnotetext{
${ }^{1} \mathrm{Cf}$. Maike Oergel, 'Revolutionaries, Traditionalists, Terrorists? The Burschenschaften and the German Counter-Cultural Tradition', in Counter-Cultures in Germany and Central Europe. From Sturm und Drang to Baader-Meinhof, edited by Steve Giles and Maike Oergel (Bern: Peter Lang, 2003), pp. 61-86 (p. 65).
} 
was animated by a desire for broad political enfranchisement and constitutional government in a united German state.

After 1806 French dominance, political and military, was perceived as such a threat that it united, at least for a short while, an unlikely coalition: absolutist princes, moderate liberal constitutionalists and radical democratic republicans would work together organising a German resistance movement and generating the anti-Napoleonic propaganda for a war of liberation. However, the differences between them, i.e. between aiming to restore absolutist monarchical rule in relatively autonomous German principalities versus creating constitutional governance for a unified nation state, reasserted themselves immediately once Napoleon was defeated. This coalition fractured between the summer of 1815 (the conclusion of the Congress of Vienna and the final defeat of Napoleon at Waterloo) and the student congress of the Wartburgfest in October 1817. It turned into open enmity from 1819-20, when the repressive Carlsbad Decrees, following the murder of the diplomat and writer August von Kotzebue, outlawed all liberal or national activities that aimed at establishing constitutional government and national unity, describing them as Jacobin, revolutionary and treasonous. Kotzebue had been killed by the Burschenschaftler Karl Ludwig Sand who perceived Kotzebue as a representative of the new conservative repression.

The political fault lines re-emerged as disillusionment with the process of instituting constitutional government was taking hold in liberal circles. Hopes for this had fuelled the Wars of Liberation, and constitutions were, albeit ambiguously, guaranteed by article 13 of the Bundesakte of June 1815, the founding document of the German Federation, negotiated at Vienna. Article 13 promised the (re)introduction of 'landständische Verfassungen', estate-based constitutions, ${ }^{2}$ in all states of the Federation, which would, to some extent, limit the absolutist power of the prince.

Constitutions were being introduced in Sachsen-Weimar, south-western states and Bavaria, but importantly the two major powers Prussian and Austria made little headway in this direction. The notion of estate-based constitutions was itself contentious: for many committed liberals and all hard-line democrats it did not go far enough towards inaugurating fully representative government because it left feudal and corporate structures in place. Post-Napoleonic political agitation, which prioritised constitutional national unity rather than anti-French sentiment against French oppression, started in the course of 1814, and increased throughout the following year as disappointment about the lack of constitutional commitment at Vienna let a more radical political wing emerge in liberal circles. The most radical groupings included the Turner and the new student associations, the Burschenschaften.

While the gymnastics movement was operating before the decisive Battle of Leipzig (1813), the Burschenschaft movement did not make an impact until the summer of 1815 . Like the Turnbewegung, it was aimed at young, (fairly) educated males, their moral and political education, and the creation of a constitutional and united German Freistaat. Both Karl Follen and his brother August were committed Turner, they were founding figures of the Burschenschaft at Gießen University where they studied, and both had been teenage volunteers in an 1814 campaign of the Wars of Liberation (although they saw no action). ${ }^{3}$

Post-1806 German political agitation is inextricably bound up with modern German nationalism; and (this) German nationalism grows out of anti-Napoleonic, and by extension, anti-French, sentiment.

\footnotetext{
2 The difficulty of translating 'landständische Verfassung' is well recognised; the term refers to representation through the traditional estates (including nobility, property-owners, the clergy, guilds and corporations etc). Assemblies made up of traditional estates have a long history in European politics. I will refer to 'landständische Verfassung' as 'estate-based constitution.'

${ }^{3}$ Frank Mehring, Karl Follen. Deutsch-Amerikanischer Freiheitskämpfer (Gießen: Ferbersche Universtätsbuchhandlung, 2004), p. 31.
} 
The reasons for this lie in the contemporary military and political landscape: the French armies were occupying German territories and Napoleon was creating client states organised in the Confederation of the Rhine, which was to be 'under his protection', i.e. beholden to him. While the French were frequently still greeted as liberators by the lower classes, the reality of occupation meant requisitioning at the least, which strained relations and created an experience of perceived oppression. Anti-French sentiment also built on cultural foundations, i.e. on over a generation's worth of cultural differentiation which, in line with European Romantic ideas, had since the Sturm und Drang set German culture against French neo-classicism, and was developing notions of the differences between Romance and Germanic languages (while, it should be noted, at the same time creating a vision of a shared European heritage). Post-Napoleonic political agitation builds on this sense of national identity but foregrounds the entitlement of the people, as a nation, to political representation. Such entitlement was already present in the 1806-13 (anti-Napoleonic rather than post-Napoleonic) agitation, e.g. in Ernst Moritz Arndt's Geist der Zeit, a running commentary on social and political developments. But while up to 1813-14 such calls for enfranchisement were always coupled with anti-French sentiments aimed against French 'oppression', after 1815 the anger was directed at illiberal German princes and their governments.

My aim here is threefold: first, to show, through a concrete and specific example, that despite the context outlined above key ideas of the French Revolution remained crucial to radical political thinking in Germany; ${ }^{4}$ second, to point out how these ideas changed on their journey into German thinking; and third, to suggest, tentatively, reasons for these changes. In this respect the essay is a contribution to the transfer of political ideas against a specific historical and cultural background.

The common ground between French revolutionary ideas and German radical political thought is their rejection of absolutist monarchy and hereditary aristocracy. This rejection distinguishes German radical political thinking from German reformist political thinking. Both support constitutional participatory politics, but reformist thinking tends to advocate constitutional monarchy, i.e. intends co-operation with the princes, and is not necessarily opposed to a loosely federal Germany, i.e. national unification is not necessarily a prerequisite for constitutional success. This reformist thinking is often associated with the idea of 'revolution from above', although it was supported by the moderate elements from below; it represents the remnants of the pre-1813 'coalition'. Radical political thinking, on the other hand, tends to reject, along with monarchy, feudal absolutism and territorial division; it is not just republican, but democratic and demands national unity. It aims at constitutional settlement(s), i.e. participatory politics based on constitutionally guaranteed rights under the rule of law, for all German territories. The differences between radical and reformist thinking focus on the extent of the franchise and, crucially, on the seat of sovereignty. Who was the sovereign? The ruler, the (limited) electorate, or the entirety of the people? This difference becomes particularly evident in the debates between 1815 and 1819 about the type of constitution that was intended, or possible, under article 13: could estate-based constitutions also include a fully representative version based on popular sovereignty, in which the sovereign is defined as the people ${ }^{5}$ This leads to follow-on questions regarding the division of powers: where

\footnotetext{
${ }^{4}$ This is not a new idea, especially for the student movement; cf. Friedrich Meinecke, 'Zur Geschichte des Hoffmannschen Bundes', in Quellen und Darstellungen zur Geschichte der Burschenschaft und der deutschen Einheitsbewegung, edited by Hermann Haupt, vol 1, $2^{\text {nd }}$ edition (Heidelberg: Winter, 1966), pp. 4-17 (pp. 5-6), Günther Steiger, Aufbruch. Urburschenschaft und Wartburgfest (Leipzig: Urania Verlag, 1967), Walter Grab, Ein Volk muß sich seine Freiheit selbst erobern. Zur Geschichte der deutschen Jakobiner (Frankfurt am Main: Büchergilde Gutenberg, 1984), pp. 498-503.

${ }^{5}$ For a debate about 'landständische Verfassungen', cf. Eberhard Büssem, Die Karlsbader Beschlüsse von 1819: Die endgültige Stabilisierung der restaurativen Politik im Deutschen Bund nach dem Wiener Kongre $\beta$ (Hildesheim: Gerstenberg, 1974), pp. 156-164.
} 
does the power of decision-making sit? Is it invested in the ruler or in the assembly of representatives?

The Jena Burschenschaft was founded in June 1815; it is traditionally recognised as the first of the new type of student organisation. ${ }^{6}$ Student organisations, in the form of Landsmannschaften (having regionally coherent membership), have a long history, as did infamously dissolute student behaviour, in terms of sexual licence, excessive drinking and disrespect for authority. The new organisation aimed at reform in all these aspects, except respect for (repressive) external authority. It sought to create a student ethos that prepared university graduates to be members of a responsible national elite imbued with a sense of public spirit and committed to (male) equality. In its political aims it represented the key demands of bourgeois emancipation: the rule of constitutional law, representation, and a free public sphere, i.e. freedom of the press, opinion, and expression. The Jena Burschenschaft was egalitarian (all members are equal in rank and rights) and the organisation had democratic structures: its constitution was voted on, its executive officers were elected. Within the University it demanded the freedom of association and of opinion. But not everybody was allowed to join (fully): non-Christians and non-Germans tended to be excluded (which would not be entirely the case at Gießen, see below). The Jena Burschenschaft was committed to national unity, which would underpin the representative, constitutional, democratic structures of the new nation state. To symbolise this prospective national unity it set out to replace the traditional regional Landsmannschaften. Follen moved from Gießen to Jena in the autumn of 1818 , when he no longer had a professional future at Gießen following a high-profile legal success on behalf a number of Hessian parishes. Follen had represented the parishes who brought a case against arbitrary new princely laws, which were intended to deprive them, already crippled financially by the costs of the wars of liberation, of some of their political independence and some of their lands. Follen proceeded to defeat their princely opponents legally and in the public sphere by mounting a successful media campaign. Grudgingly the new laws were revoked. ${ }^{7}$

At the same time as the Jena Burschenschaft was established, the student organisation of 'Die Unbedingten' (the Unconditional ones), also called 'die Schwarzen' (the Blacks), headed by the Follens, was beginning to emerge at Gießen. Initial efforts in the winter of 1814-15 around Karl's 'Teutsche Lesegesellschaft zur Erreichung vaterländischer Zwecke' were followed by a rapid succession of different student groups between 1815 and 1818, which in a process of radicalisation largely directed by the Follen brothers, continuously disbanded and reformed. ${ }^{8}$ They all shared the same republican, democratic outlook coupled with a belief in the need for national unity and, increasingly, the necessity of militancy to achieve their political aims.

Right from the beginnings of the 'Lesegesellschaft' the Follens' organisations had a dress code: black velvet cloak, large (white) collar worn over the cloak, black velvet beret with a cross (worn on shoulder-length hair) and a small dagger. ${ }^{9}$ This gave them their nickname, the '(Gießener) Schwarzen'. The dress code was derived from early modern (German) clothing, from what they considered a 'deutsche Volkstracht' (German folk/national costume). This sartorial reference alluded to the period of the German Reformation, a key event in religious and political terms in the historical thinking of the contemporary movement for German national unity since Schiller and Fichte had styled it as a German achievement of national and world-historic significance in Aesthetic Education and Addresses to the German Nation respectively. The 'Volkstracht' also served to symbolise an egalitarian national dress. The Blacks' secret sign was the acronym MHBG, which stood for the lines

\footnotetext{
${ }^{6}$ For a summary cf. Oergel, 'Burschenschaften', pp. 65-68.

${ }^{7}$ Mehring, pp. 60-61.

${ }^{8}$ Mehring, pp. 37-42.

${ }^{9}$ Mehring, p. 40.
} 
'Im Herzen Muth, Trotz unterm Hut, am Schwerte Blut, macht alles gut'. ${ }^{10}$ Credited with being a slogan by Jahn, ${ }^{11}$ it appears as a quatrain under the title of the first section of Arndt's Geist der Zeit II $(1809 / 13) \cdot{ }^{12}$

The lines illustrate the committed militancy with which they approached their struggle, espousing violence and potential martyrdom. The notion of a holy war ('heiliger Krieg') was a common topos in the context of the Wars of Liberation. Theodor Körner invoked it in his poem 'Aufruf' in Leier und Schwert (1813), ${ }^{13}$ and Arndt used it in Landsturm und Landwehr (1813-15). ${ }^{14}$ Follen was certainly familiar with Körner's poem, ${ }^{15}$ and it is more than likely that he knew Arndt's pamphlet. A terrorist act soon followed - Karl Sand's assassination of August von Kotzebue in March 1819. Sand had from 1818 been a law student at Jena and has been directly linked to the Follens and the radical elements in Jena (and Gießen). ${ }^{16}$ Sand targeted Kotzebue because he considered him a supporter of a corrupt conservative regime. The ensuing Carlsbad Decrees made the Follens political criminals and drove them into exile.

Follen saw the student organisations as prototype free states, governed publicly by the general will of their members/citizens. To this end he produced in 1816 a constitution for future student bodies, the Ehrenspiegel, ${ }^{17}$ which was to be the basis of the latest Gießen organisation under his auspices. This new body was a voluntary organisation, a student joins through an individual act of free will; it has democratic structures, decisions are made after public discussion by general (almost) secret vote and its officers are elected. Its legislative is based on 'verfassungsmäßig ausgesprochenen Gemeinwillen' ( $\$ 3$, 'the constitutionally expressed general/public will'), and it was supposed to create, and act within, its own public sphere. Its judiciary is freely elected, but the identity of its members is kept secret. Follen summarises the activities of the new student movement in his 1819 essay on universities.

[Es] erhob sich unter den Burschen von Giessen das Urbild des christlichen deutschen Freistaats, wo bei voller Gleichheit der Ehrenhaften, der, in allgemeinen Burschenversammlungen durch freie, gemeinsame Verständigung hervorgebildete Gesamtwille in Burschensachen herrschte, und wo in engem Zusammenwirken aller judendlichen Kräfte, in Sitte und öffentlicher Meinung, ein gläubiges, volkstümliches Streben, ein wissenschaftliches, turnerisches, freibürgerliches Treiben, sich entfaltete. ${ }^{18}$

10 'Courage in my heart, Defiance under my hat, Blood on my sword, Makes everything good.' Unless otherwise stated all translations are my own.

${ }^{11}$ Mehring, p. 40, based on Hermann Haupt, Karl Follen und die Giessener Schwarzen (Gießen: Tölpelmann, 1907), p. 10.

${ }^{12}$ Geist der Zeit II, $1^{\text {st }} 1809,2^{\text {nd }}$ edition (London: Boosey, 1813), p. 1 . The first edition had a very small circulation and is exceedingly rare. As the $2^{\text {nd }}$ edition contains 'alternations' (is 'verändert'), it has not yet been possible to ascertain whether it appeared already in the 1809 edition, in which case it would precede the Turnbewegung, and Jahn may have picked it up from Arndt.

${ }^{13}$ Theodor Körner, 'Aufruf', I. 11, in Sämmtliche Werke, vol 1, 5 $5^{\text {th }}$ edition (Berlin: Grote, 1885), p. 15.

${ }^{14}$ Ernst Moritz Arndt, Was bedeutet Landsturm und Landwehr? (Cologne: Rommeskirchen, 1815), p. 16. 'Der Krieg, der nicht für Raub und Eroberung geführt wird, sondern für das Vaterland und die Freiheit, ist ein heiliger Krieg.'

${ }^{15}$ Mehring, p. 31.

${ }^{16}$ Mehring, pp. 70-79; Günther Heydemann, Karl Ludwig Sand: Die Tat als Attentat (Hof: Oberfränkische Verlagsanstalt, 1985), pp. 78-82.

${ }^{17}$ Karl Follen, 'Ehrenspiegel der Burschenschaft zu Gießen', in Between Natives and Foreigners. Selected Writing of Karl/Charles Follen (1796-1840), edited by Frank Mehring (Bern, New York: Peter Lang, 2007), pp. 318.

${ }^{18}$ Karl Follen, 'Beiträge zur Geschichte der teutschen Sammtschulen', in Between Natives and Foreigners, pp. 19-44 (p. 19). Among the Burschen (students) at Gießen there arose the vision of a Christian German free 
A crucial aspect of the concept of liberty presented here is its legitimation by publicness; public debate and activity are to create public general spirit (Gesamtwille) and public opinion, which is based on majority decisions. However, individuals are free to make their own decisions; while they are governed by the laws they make, they are ultimately beholden only to their own conviction and the jurisdiction of their individual conscience, 'nur so zu handeln, wie es Überzeugung und Gewissen gebietet' (Ehrenspiegel, p. 4, to act only as one's conviction and conscience demands). Clearly visible is the influence of the Lutheran priority of the individual's conscience in a corrupt world, as well as the impact of Jakob Friedrich Fries' ethics based on personal conviction. Fries was professor of Philosophy at Jena at the time and a key influence on the Burschenschaft movement. ${ }^{19}$ NonChristians and non-German students could attend the public discussions and debates and were allowed to raise objections and make observations, but could not vote or bring their own motions (Ehrenspiegel, §9, 10, 17a).

In October 1817 the 'Wartburgfest', a gathering of these new Burschenschaften, brought the radical as well as moderate aspects of the student body to the fore, but confirmed that the general aim remained to drive forward the constitutional movement, which for most included a united Germany. That these political activities were by the conservative authorities considered political radicalism and associated with the Revolution is evident from the vocabulary used in connection with the Burschenschaften and Turner: the Wartburgfest was dubbed a new 'storming of the Bastille', Burschenschaftler were attacked as 'Jacobins', Jena was described as a 'Jakobinernest'. ${ }^{20}$

Follen did not attend, but a number of Gießen Blacks did. Follen was in the process of completing his law doctorate, and soon after the Wartburgfest took the next step in his efforts to bring about political change in Germany: together with this brother August he began working on a constitution for the new Germany, the 'Grundzüge für eine Künftige Teutsche Reichsverfassung', which was written in the winter of $1817-18 .{ }^{21}$ Perhaps politically the most radical German constitutional attempt of the time, an annotated draft is extant because it was secured as evidence by postCarlsbad surveillance agents. The 'Reichsverfassung' shares many features with the French Constitution of June $1793,{ }^{22}$ the most radical of the French constitutions, which was ratified by the Convention, but never implemented, and discarded in 1795 .

Both are fully representative constitutions, i.e. based on popular sovereignty, which means the 'people', which is comprised of the citizens, is the sovereign; Follen speaks of 'des Volkes rechtliche Allmacht und Alleinmacht' (§4, power resides fully and only in the people), the 'Volk' exercises 'gesetzgebende', 'richterliche und vollziehende Gewalt' (§5, legislative, judicial and executive power). In similar vein, the 1793 Constitution states that 'the sovereign people embraces the whole of French citizens' (article 7) and 'the population is the only basis of national representation' (article 21). This sovereignty is in both cases exercised by universal (male) suffrage through electing direct representatives. Both constitutions are based on the division of power; and both feature a pyramid

state, in which all (honourable) members are equal and where the general will, which has emerged in free communal agreement, rules all student affairs. In this state, where youthful vigour, moral customs (Sitte) and public opinion closely interact, a faithful, popular striving and intellectual and sporting activities developed among its free citizens.

${ }^{19} \mathrm{Cf}$. Gerald Hubmann, Überzeugungsethik und politisches Handeln. Jakob Friedrich Fries und die deutsche Tradition der Gesinnungsethik (Heidelberg: Winter, 1997).

${ }^{20}$ Cf. Heydemann, p. 73.

21 'Grundzüge für eine Künftige Teutsche Reichsverfassung', in Between Natives and Foreigners, pp. 45-57.

${ }^{22}$ As quoted on http://oll.libertyfund.org/pages/1793-french-republic-constitution-of-1793 which is based on the edition by Francis Lieber in his On Civil Liberty and Self-Government, $1^{\text {st }} 1853$, 3rd revised edition, ed. by Theodore D. Woolsey (Philadelphia: J.B. Lippincott \& Co., 1883). Franz Lieber was a German-American professor of history and political economy, a former Burschenschaftler, gymnast, and veteran of the Greek war of independence, who emigrated to the United States, arriving in Boston in 1827. 
of democratic representative structures from local up to national level. Both provide for stringent measures to safeguard the integrity of this sovereignty by publicity and public-ness, using the regulative forces of the public sphere as the forum where the general will emerges. From these premises derive a number of shared features.

The national assemblies of elected representatives, the Assemblée nationale ${ }^{23}$ and the Reichstag respectively, hold the legislative (and highest) power; they determine laws, the budget, war and peace, foreign relations, and they choose the executive. In both the function of the executive is conceived as purely administrative (article 65 in the 1793 Constitution; §25, 28 and 29 in

'Reichsverfassung'). The executive civil servants, such as executive administrators and the judiciary, are chosen by elected representatives. Both envisage a complex administrative organisation of the national territory to enable and safeguard popular sovereignty. Although administratively divided, the national territory is indivisible to ensure that the same laws apply to all citizens. Territorial national unity is seen as the precondition to guarantee anti-feudal and anti-absolutist government. Both share the same keen sense that governing must be public to ensure that power is not abused; hence, parliaments and the courts conduct their business in public (cf. article 45, 94, 96 and $\S 8$ respectively), and there is a free press ( $\$ 18$ and article 122 ). All citizens are equal before the law (article 122 and §4), and both constitutions envisage general conscription (article 109 and §32). There can be little doubt that French ideas, as expressed in the 1793 constitution, inform Follens' constitutional efforts. But there are also key differences.

The Follen draft is much more detailed regarding how to ensure democratic consensus at all levels: it spells out how every resolution has to be presented and voted on from village to Reichstag, all levels have fora of discussion and decision-making, including decisions on all functionaries/officials (parishes can pass a vote of no confidence on their vicars, §11), even 'die Gemeine ist ein Freistaat' $(\S 22$, the parish is a free state), one of the many Follen envisaged existing and interlinking in the new Germany. But this is a difference of degree, not essence.

In both constitutions the definition of citizenship is linked to the right to vote, which in fairly universal male suffrage involving all classes in participating in politics. Apart from allowing only male voters, both put some limitations on the franchise. The 1793 Constitution stipulates it should include every man who 'lives from his labour', specifies the necessary age (21), and focuses on a connection with France, i.e. born in France, married to a Frenchwoman, owning property in France, supporting an old (French) man, having adopted a (French) child. The 'Künftige Reichsverfassung' stipulates that anyone who is 'unbescholten' (without blame) and 'wahrhaft gemacht' (has identification) can be elected, while voters have to be 'dies beides und ein Mann mit unabhängigem Hauswesen' ( $\$ 5$, both without blame and have identification, and an independent household). This latter rather propertybased, middle class proviso is revoked in the marginalia, everyone who has achieved what is perhaps best described as civil maturity can vote: 'Wähler und wählbar ist jeder Teutsche, der für seine eigentümliche Leibes- und Geistesbeschaffenheit, nach dem Urteil der Ärzte und der Schule, zum selbständigen Bürger ausgebildet, vor dem Volke wehrhaft und des Mitgenusses des heiligen Abendmahles teilhaftig gemacht worden ist. ${ }^{24}$ The Follen constitution prominently uses the signally French terminology of citizenship. In their political capacity people are 'Bürger' and a male becomes adult when he reaches 'bürgerliche Reife' (civil maturity), which is certified by his teachers and medical professionals (\$15). Only in the marginalia is the right to vote explicitly linked to being German ('jeder Teutsche'). In the running text this is implicit, voters are members of the 'Volk', a term that connotes social as well as ethnic identities. Voters have to be members of the German 'Volk', and their identity is defined culturally, as set out in $\S 1-3$, which define the German people:

\footnotetext{
${ }^{23}$ The French National Conventions is to deal with matters of the constitution (articles 115-117).

${ }^{24}$ Cf. Amendment to §5, cf. Between Natives and Foreigners, p. 456. Every German can vote and be elected who has been certified by doctors and his school as being an independent citizen in accordance with his own individual physical and intellectual properties, who can carry arms and has partaken of Holy Communion.
} 
they are characterised by a shared language ('gleiche Sprache'), shared historical memory ('gleiche geschichtliche Erinnerung'), and the same faith ('gleicher Glaube'). $\$ 3$ concludes: 'Das Reich ist eine Vereinigung aller Teutschen.' (The Reich is the union of all Germans.) In this emerges the key difference: the importance of cultural identity in the Follen draft. It is evident in three differences of essence between the 'Künftige Reichsverfassung' and the 1793 Constitution: the focus on religion, cultural history, and education.

Religion. Follen's German Free State is animated by a potentially ecumenical Christianity based on the teachings of Christ and the New Testament $(\$ 10)$, revealing its strongly Protestant roots and preaching freedom, truth and love (\$11). It proposes a Christian state church, which is fully involved in promoting moral citizenship. The church has a democratic organization parallel to that of popular sovereignty. It is, however, not mandatory that a citizen attends (this) church regularly, everybody is free to follow other (Christian?) denominations 'Glaubenszwang ist überall nicht' (religious coercion does not exist) and the 'Hausandacht ist ungestört' (private devotion is undisturbed at home). The Christianity Follen envisages has (some) features of a universal humanism. Religions that are 'den Zwecken der Menschheit zuwider' (contrary to the purpose of humanity) will not be tolerated. Judaism, however, is specifically excluded. The 1793 Constitution makes no provision for the influence or inclusion of religion or the church in the processes of exercising popular sovereignty or public life. Religion only features under 'rights': its free exercise is guaranteed (article 122). One is tempted to wonder to what extent this is linked to the fact that there was no established (Protestant) tradition of religious dissent in France, and as such no politically viable 'dissenting' tradition, onto which a new political vision could be projected, as was the case in $16^{\text {th }}$-century Germany and $17^{\text {th }}$-century England. In France the Catholic Church was fully implicated in the absolutism of the ancien régime, hence perhaps the emphasis is on a fully secular constitution.

Education. The fundamental importance of general education is evident in Follen's definition of citizenship: attending (a free comprehensive) school is considered essential for attaining citizenship maturity, it is mandatory between the ages of 8-16 (\$12). The structure of the national education system (schools and universities) is presented in similar detail as that of the church; ${ }^{25}$ both schools and universities are to be the training grounds of democracy and citizenship, they are themselves Freistaaten. The 1793 Constitution does not discuss education or a school system, it only mentions the 'right' to 'general instruction' (article 122).

The last key difference is the historically constructed cultural identity (and possibly historically constructed ethnicity). 'Teutsche sind ein Volk.' ( $\$ 1$, Germans are one people). This is based on shared language, historical memory, and Christianity. These three features are becoming fairly standard cultural markers used in the broader (German and British) discussions of the time to identify a modern European identity and within this, modern national identities. ${ }^{26}$ These discussions of cultural identity are also intricately related to the debates about how to define new social collectives and how to enfranchise them. ${ }^{27}$ In this discourse historical memory sometimes

\footnotetext{
${ }^{25}$ The subjects to be taught in school are prescribed, and balanced between academic and vocational subjects; they are to be chosen according to ability, inclination, and the pupil's potential future choice of profession (ibid.) The society Follen envisages is a meritocracy, with career progress based on ability and qualifications. ${ }^{26}$ Cf. Maike Oergel, 'Germania and Grea(ter) Britain: German Scholarship and the Legitimization of the British Empire' in Angermion. Yearbook of Anglo-German Cultural Relations 5 (Berlin/New York: de Gruyter, 2012), pp. 91-118; and "Germanisierung" als romantisches Kulturmuster in der englischen Geschichtsschreibung des 19. Jahrhunderts', in Praxis und Diskurs der Romantik 1800-1900, edited by Norman Kasper and Jochen Strobel (Paderborn: Schöningh, 2016), pp. 99-116.

27 'The Germanic and the Gothic. Creating an Identity of Northern Liberty and Communal Responsibility to enfranchise a New Collective' in Maike Oergel. Zeitgeist. How Ideas travel. Politics, Culture and the Public in the Age of Revolution, forthcoming 2018.
} 
foregrounds the Reformation, sometimes aspects of medieval culture. One might hesitate to call Follen's identity constructions purely ethnic, as the draft does not state that membership depends on German blood (whatever that may be), although being 'German' in terms of language and historical memory was a key factor. The 1793 Constitution also explicitly acknowledges that being French by birth bestows citizenship, although it spells out clearly that this right is easily acquired by those not born in France (article 4). It also makes no conditions regarding cultural identity based on language, history, or religion. It does, however, make claims on its citizens' political persuasions: the rights of French citizenship are forfeit if the citizen accepts 'offices of state, or favours which do not proceed from a democratic government' (article 4). The focus on cultural identity is the key difference between German and Western European concepts of citizenship, it has been taken as evidence that German political thinking lacks the influence of rationalistic natural law.

Is the lack of influence of natural law the only reason for these shifts? Why was the German 'Jacobinical' popular sovereign underpinned by religion and shared historical culture, which is inculcated by (moral and political) education? The focus on education is drawn from the preoccupations of the preceding generation, especially Schiller, Fichte, and Humboldt. Follen had read Fichte, whose Reden an die deutsche Nation had legendary status among the anti-Napoleonic freedom fighters, and he was a huge Schiller-fan. Both Schiller and Fichte wrote their education plans in response to the Revolution and its consequences, Schiller under the impression of the events of 1793, Fichte reacting to the developments after 1806.

These education plans, outlined in Schiller's Aesthetic Education and Fichte's Addresses, are in both cases their authors' responses to the 'failure' of the French Revolution, which both of them had initially welcomed enthusiastically. For both it was a failure in terms of France descending into the despotic tyranny of party politics and intense factionalism. Both concluded that the French had not been ready for revolutionary social and political upheaval because they lacked the moral preparation for this. Such preparation was provided, according to Schiller and Fichte, by the implementation of the ideas of the Reformation. I see this as their determined attempt to 'save' the ambitions of the Revolution. The cultivation of an independent conscience and moral responsibility had to come first, before a morally mature, free citizen can emerge who can shoulder the political responsibility of popular sovereignty and the liberation from hierarchical structures which oppress the people, but which also establish order. In short: moral reformation has to precede political revolution. This is exactly what Follen demands.

For both Fichte and Schiller Luther's Reformation is the starting point for making such an education possible, and it is a project which needs to continue. This explains the role of Protestant Christianity in shaping able citizens in Follen's political plans. It is linked to the notion of inner conviction Überzeugung - which must inform moral action, and which was establishing itself as the basis of political action at this time, when the Jena professor of philosophy Jakob Friedrich Fries adapted Kant's moral philosophyfor practical political action. Fries was one of the 'political Jena professoriate', he addressed the students at the Wartburgfest and is likely to have influenced, or confirmed, Follen's thinking in this context. ${ }^{28}$

The connection with an 'indigenous' event (the Reformation) and tradition (Christianity) anchored the revolutionary liberation process in historical progress and gave it a trajectory. Follen's martial poem, Großes Lied, makes explicit the link between Luther's liberation movement and the objectives of the current liberation movement, spearheaded by the students: 'Luther, das freie Blut' was 'Die Geißel der Hohen' (scourge of the upper classes) and 'Der Wahrheit Flammberg, der Taten Dolch'

${ }^{28} \mathrm{Cf}$. Hubmann, Ethische Überzeugung. 
(the flaming mountain of truth, the dagger of activism). ${ }^{29}$ The Wartburgfest itself was explicitly making this link. In the place where Luther translated the Bible into the German vernacular while in hiding from his imperial and papal persecutors, the students gathered in October 1817 to commemorate both the fourth anniversary of the Battle of Leipzig, i.e. the Wars of Liberation (October 1813) and the $300^{\text {th }}$ of Luther nailing his theses to the church door in not too distant Wittenberg (October 1517).

Follen's Lied suggests that he was intending to bring about a German revolution that would violently overthrow the existing structures of rule, abolish all hereditary rights and all forms of unchecked exercise of political power in a way that is clearly modelled on the course of the Revolution in France. The different parts of the 'Lied' were written around the same time as the draft constitution and were circulating in 1818. It shares many features with Körner's poetry, especially the focus on the willing acceptance of patriotic martyrdom, the glorification and transubstantiation of violence in battle and the fervent denunciation of the enemy as evil, all markers of a holy war. Körner, invoking Schiller, presents the conflict as in tyrannos, fighting tyrants, but only very occasionally hints at restructuring (German) social power. ${ }^{30}$ Follen on the other hand is clearly suggesting a struggle for popular sovereignty when he speaks of 'Volkesmacht' ( $p .58$, the power of the people) and the need to restore 'Volksfreiheit' (p. 59, the freedom of the people). This can only be achieved by a violent revolution which will kill both despotic rulers and their servile slaves: 'Hin auf Knecht und Zwingherrn, die dich hudeln,/ Sei ein Volk, ein Freistaat' (p. 60) or 'Tod des Herrn wie des Knechtes/ Fordert der Engel des Menschengeschlechts' (p. 69). ${ }^{31}$ The notion of universal human as well as civil rights is never far from the surface. The poem is anti-monarchic and anti-divine right: 'Stürzt um die vergötterte Schande;/ Von dem Throne die Fürsten/In Flammen den Thron' (p. 69). ${ }^{32}$ It rejects despotic royal and clerical authority in favour of a new collective: 'Fort Zwingherrn-, Adel- und Pfaffenbrut/ Soldaten und Pöbel zur Höllenglut!/ Ein Reich freier Bürger,/ Ein Gott, Ein Volk, Ein

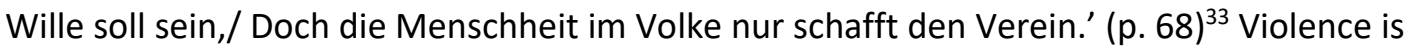
inevitable, condoned, and embraced: 'Dann wird's, dann bleibt's nur gut. [...] Wenn du Gewehr und Axt,/ Schlachtbeil und Sense packst,/ Zwingherrn den Kopf abhackst,/ Brenn, alter Mut!' (p. 62). ${ }^{34}$ The wording clearly recalls the motto MHBG. This is necessary because: 'Schlagt euer Plager tot,/ Rettet das Land!' (p. 62) and 'Eine Menschheit zu retten aus Knechtschaft und Wahn,/ Zur Blutbühn, zum Rabenstein führt unsere Bahn.' (p. 64) 35 The Lied (and the constitution) are clearly situated in a post-Napoleonic political landscape: liberation from French occupation has been achieved, but not from the 'ancien régime', reinstated by the Congress of Vienna. This is why the 'Volk's military struggle has to turn into militant struggle to throw off its German oppressors: that is to say, its despotic, oppressive and illegitimate rulers.

\footnotetext{
${ }^{29}$ Between Natives and Foreigners, pp. 58-71 (p. 68). What is printed in Mehring's edition is the entire collection of all parts, each with individual titles, that were circulating at the time under the name of 'Großes Lied', Mehring, pp. 440-441.

${ }^{30}$ As in 'Aufruf', the holy war is 'kein Krieg, von dem die Kronen wissen', I. 10 (no war of which the crowned heads/the monarchies know'. Körner is mostly supportive of monarchical rule in a united Germany, eulogising the Prussian and Austrian eagles (symbols of crowned rule), patriotic kingship, and the Prussian Queen Luise. 31 'Bring down slaves and slave masters, who treat you ill, be a nation, be a free state' and 'the angel of the human race demands the death of masters and slaves'.

32 'overthrow the icons of shame, princes off their thrones, thrones into the flames'

33 'To hell with the princes, to hell with the spawn of the aristocracy and clerics, away with (hired) soldiers and scum, One Reich of free citizens, one God, one people, one will shall be, only the people's humanity creates the union.'

${ }^{34}$ 'It will only be right and succeed if you grab gun and axe and butcher's knife and scythe and hack off the slave master's head. Burn, ancient courage!'

35 'Bludgeon those that torment you to death, Save the country!' 'In order to save humanity from slavery and madness, our path leads to the scaffold, to the Raven's Stone.'
} 
The "Schwarzens" dress code was designed to recall and legitimate their historical trajectory, it is early modern, puritanical, and protestant, and so is to some extent the language used in the orbit of Follen's agitation activities. While the 'Künftige Reichsverfassung' and the Ehrenspiegel (excepting its name) are both largely written in contemporary legal German, Follen's language does not only in his propagandistic poems hark back to early modern German, but also in his summary of the recent student movements, where he speaks of 'Sammtschule', 'Wahlfeld von Leipzig', 'das Kreuzschwert der Freiheit'. ${ }^{36}$ This is not specifically a Follen trait, but common to the radical liberal-democratic nationalists, e.g. Turner circles.

This harking back to an imagined important and legitimising national past has been summarised as Deutschtümelei (Teutomania), and criticised then ${ }^{37}$ and later. It has been widely seen as evidence of the politically immature, backward and illiberal nature of German nationalism, and an innate racism, the harbinger of worse to come. ${ }^{38}$ For Follen the language and the 'altdeutsche Tracht' were a political statement - he prescribes 'allgemeine Volkstracht' to be worn at official occasions (voting, law courts etc) in the constitution (\$19) - presumably to legitimate progressive politics that enfranchised a broad sweep of citizens in a way that did not imitate current, discredited representations of power. And the challenge was understood as such by conservatives. Steiger claims that conservative authorities saw the 'Altdeutsche Tracht' as a 'German version of the clothes of the sans-culottes' ${ }^{39}$ To what extent Follen is credited with being a fore-fighter for German democracy, or inversely considered a radical Jacobin, has tended to depend on the interpretation of the Teutomanic tendencies in his texts. ${ }^{40}$

In many respects, Deutschtümelei was a model exercise in imaginary identity-building, which Follen clearly felt was necessary to constitute the collective sovereign of German popular sovereignty. This sovereign was not as evident as, for example, its French counterpart, geographically or politically at least. Follen felt it needed stating in $\S 1$ that, 'Teutsche sind ein Volk', that they are 'gleichartig' (§2) in terms of cultural heritage and choice of religion. The Follen constitution goes to considerable length to accommodate regional diversity, recognising the federal nature of the old Reich, and perhaps also its soft borders. ${ }^{41}$

\section{Modern Essentialist Identities: Follen and Fanon}

In its fundamentalist essentialism Deutschtümelei shares some features with the identity construction familiar from the colonial liberation struggles, perhaps initially especially with the négritude movement of Pan-Africanism from the 1930s to 1950s, which also focused on a recovery of historical roots to create an identity that has the strength to inspire resistance and insurgency, as well as a new polity, and which prioritised ethnic culture, if not ethnicity per se, as the key criterion

36 'Geschichte der teutschen Sammtschulen seit dem Freiheitskriege', p. 19.

${ }^{37} \mathrm{Cf}$. Saul Ascher, Die Germanomanie. Skizze zu einem Zeitgemählde (Berlin: Achenwall und Comy, 1815).

${ }^{38}$ There are totalitarian and anarchic tendencies: the 'ethics of conviction' liberate from all external law. Also see their motto (MHBG), which is violent and rebellious without clear content.

${ }^{39}$ Steiger, p. 55, 'deutsche Abart der Sansculotten Tracht' .

${ }^{40} \mathrm{Cf}$. Grab, who sees it as an 'eigentümliche Vermengung progressiver and reaktionärer Tendenzen' ( $\mathrm{p} .498$ ); Steiger, a GDR academic, in 1967 stressed the progressive aims and intentions of the students and saw the Teutomania in this light (pp. 33-57), for him 'aggressive nationalism and chauvinism' were a product of the time after 1849 and linked to reactionary German imperialism' (p. 57). The editors of Blut und Paukboden, on the other hand, explicitly place the entire movement within 'Konservatismus', identifying it as part of the continuity of 'anti-democratic thinking'. Blut und Paukboden. Eine Geschichte der Burschenschaften, edited by Dietrich Heiter, Michael Gehler, Alexandra Kurth, Gerhard Schäfer (Frankfurt am Main: Fischer, 1997), p. 12.

${ }^{41} \mathrm{Cf}$. $\S 2$ and p. 456 for amendments. Regarding the 'soft' borders, the draft also includes the Swiss, Alsacians and Frisians, which could be read as a großdeutsch land-grab. But it is significant in this context that he talks about people ('Schweizer, Elsässer, und Friesen'), not territories, which could suggest he is thinking of voluntary, possibly individual accession. 
for inclusion. ${ }^{42}$ It also (albeit on a more global scale) dealt with an identity without a clear territory, let alone a state, and without a clearly defined 'people'.

For négritude, black identity rests on culture, and the awareness of cultural identity will lead to a changed politics. Focused on black culture in its original and indigenous state, it has recourse to 'the centers of African civilizations, their religious systems, their forms of government, their artistic wealth', which is opposed to an oppressive, exploitative, and decadent white culture. ${ }^{43}$ In his essay 'African Negro Aesthetics' Léopold Sédar Senghor proclaimed that 'Emotion is Negro, reason is Hellenic'.$^{44}$ This presents an approach to cultural identity in which historically organic identity is given essentialist qualities. Senghor's statement has remained controversial, and he frequently had occasion to explain it. Négritude, and especially Senghor, have been criticised for essentialism. ${ }^{45}$ Somewhat ironically in our context, Senghor's point is also aimed against a French hegemony, and in cultural and intellectual terms especially against the analytical type of rationality, or 'French (neo)classical reason'. Essentialism is still present, a generation later, in Frantz Fanon's Wretched of the Earth (1962). Although it is now critically mediated, it still comes with a focus on national culture. Fanon also engages with the use of violence to liberate the nation. 'National liberation, national reawakening, restoration of the nation to the people or Commonwealth [...], decolonization is always a violent event. ${ }^{\prime 46}$

Fanon is critical of the universalism of Pan-African négritude, which for him negates the differences created by different concrete historical situations inhabited by U.S. blacks or blacks in Africa, struggling for or with their independence. He is dismissive of the intellectual talking about "NegroAfrican" culture', directly alluding to Senghor, which to him only reflects a white colonial construction of colonised people (168-170). Fanon insists on a more specific national identity and culture. He recognises 'organic' national identities as constructed, but this does not prevent him from recognising their efficacy and deploying them. 'All the men and women fighting French colonialism in Algeria with their bare hands, are no strangers to the national culture of Algeria. The Algerian national culture takes form and shape during the fight.' (168)

There are two similarities to Follen's approach: firstly, Fanon, too, proposes to revitalise a buried and belittled national culture of the past in order to create a specific and inspiring identity. Historical precedents, especially heroic deeds, are to be made relevant to the current situation. And secondly he also establishes a link between the cultural identity and committed militant activism to liberate an oppressed and colonised homeland in order to establish a fairer participatory political (and economic) system.

When the colonized intellectual writing for his people uses the past he must do so with the intention of opening up the future, of spurring them into action and fostering hope. But in order to secure hope, in order to give it substance, he must take part and commit himself body and soul to the national struggle. [...] To fight for national culture first of all means fighting for the liberation of the nation, the tangible matrix from which culture can grow. One cannot divorce the combat for culture from the people's struggle for liberation. [...] We must work and struggle in step with the people. [...]

\footnotetext{
42 The essay on négritude in the Stanford Encyclopedia of Philosophy (https://plato.stanford.edu/entries/negritude/) accessed February 2018, outlines how the definition of Black African culture formed the basis for a counter-identity to white culture. In the publications of the late 1940s it was especially literature, from poetry to essay-writing, that was seen as establishing this identity, was necessary to achieve liberation.

${ }^{43}$ Cf. ibid, quoting from Jane Nardal's article 'Internationalisme noir' of 1928.

${ }^{44}$ Written in 1939, the essay was published in 1956 in Diogenes (vol 4, issue 4).

45 The most famous critique is perhaps Sartre's label of 'anti-racist racism' ('Orphée noir', prefatory essay to Senghor's Anthologie de la nouvelle poésie négre et malgache, 1948).

${ }^{46}$ Frantz Fanon, The Wretched of the Earth, translated by Richard Philcox (New York: Grove Press, 2004), p. 1.
} 
National culture is the collective thought process of a people to describe, justify and extol [chanter, to sing] the actions whereby they have joined forces and remained strong. National culture in the underdeveloped countries, therefore, must lie at the very heart of the liberation struggle. (pp. 167168)

Similar to Follen, Fanon advocates a dedication to a total war against the oppressor based on an identity driven by historical collective popular culture, expressed here in inspiring national poetry. Historicism alone is not enough, it must be coupled with militant activism. National literature becomes 'combat literature', 'it calls upon a whole people to join the struggle for the existence of the nation' (173). ${ }^{47}$ The result is a meshing of military and militant struggle, inspired by a separatist identity and turning to partisan-terrorist warfare. 'In a colonized country nationalism in its most basic, rudimentary and undifferentiated form is the most forceful and effective way of defending national culture.' (p. 177) It has the aim to restore 'national sovereignty' (p. 178). Follen appears to have thought along similar lines. The impetus of the militant struggle of the Wars of Liberation, the democratic ('Jacobin') political opposition in Germany overlapped with the construction of a popular national culture in a not dissimilar way. For Fanon the liberation of territory is essential for building a new society in a new state: one of 'our fundamental tasks $[. .$.$] is to liberate the national territory'. ( p$. 170)

In a notable difference to Follen, however, Fanon describes the re-assimilation, and re-immersion, of especially the colonised intellectual into the 'people', complete with authentic language and clothing, with considerable ironic distance.

The flowing dress of the boubou is regarded as sacred and the shoes from Paris or Italy are shunned for babouches. The language of the colonizer suddenly scorches his lips. Rediscovering one's people sometimes means in this phase [...] going as native as possible.' (p. 158)

The features of the process Fanon describes are however the same as Follen's 'altdeutsche Tracht' and the Luther-esque language of his songs. Fanon may be ironising the unreflected Romantic exoticism of the first generation of négritude - which seems to equate with Follen's - but it remains to him an essential stage of development towards the militant activism that will liberate both territory and culture.

Oral literature, tales, epics, popular songs, previously classified and frozen in time, begin to change. [...] it becomes an authentic form of entertainment that once again has cultural value. Colonialism knows full well what it was doing when it began systematically arresting these storytellers after 1955. (p. 174)

So did the conservative authorities after 1819. Follen's Großes Lied was circulating in radical student groups; Sand incorporated parts of it into a pamphlet he distributed in October 1818, which was directly aimed at the 'teutsche Menge', the German lower-class masses. ${ }^{48}$

There are evident differences between the oppression associated with colonialism and that associated with either French occupation and political control over Europe between 1806 and 1813 or the Restauration after 1815. But there are similarities between Follen and Fanon, who both as intellectuals and as highly qualified professionals worked to create popular collective identities, based on national culture, that would help inspire the overthrow of an oppressive and exploitative system. The pattern of their resistance, in which the spirit of violated historical identity animates a violent struggle to liberate territory and establish a fair and participatory state, is similar, which bearing in mind the differences regarding place and time - could suggest that this is a generic

\footnotetext{
${ }^{47} \mathrm{Cf}$. 'Schlagt eure Plager tot, Rettet das Land!' above.

${ }^{48}$ Cf. Mehring, pp. 76-77.
} 
pattern. To what extent one is prepared to accept that the oppression Follen was fighting was sufficiently similar to the one Fanon was facing is open to debate. It must however be clear that Follen saw the situation as desperate and extreme, that he perceived a state of unbridgeable difference between the rulers and their party, and the 'people'.

One might be inclined to consider the situation of the German subjects of 1806, 1815 or 1820 not in the same category of 'oppressed-ness' as that of coloured colonised subjects. But it is worth more research to investigate whether there are subtle similarities between how colonised black people in the twentieth century and disenfranchised Germans around 1800, and especially between 1806 and 1820 , saw themselves in terms of lacking cultural and political self-determination.

This takes me back to the nexus between the nation, the people, and freedom, and its crux: the popular sovereign which embodies the general will, and which exercises its freedom by doing so. This is a question of who can be enfranchised, socially, economically, but also 'culturally'. Who is of the people? If borders are stable and supported by visible cultural and linguistic demarcation, delineating 'the people' can be relatively straightforward. But if borders are changing and arbitrary, which is a common feature in central Europe and in the colonial world or in a diaspora, identity is harder to formulate, and tends to be defined by a mix of culture, tradition, and ethnicity. This is especially the case if there is a perception of unwanted domination and if there are reasons why assimilation with the dominant power is not easily possible.

Follen may well have seen a connection between disenfranchised Germans and black slaves. In 1824 his exile in Switzerland, where he was holding an academic post at the University of Basel, was no longer safe, and he was forced to emigrate to the United States. He settled in Boston and from the late 1820s built up German teaching at a nascent Harvard; from 1830 he held the first chair of German language and literature in the United States, at Harvard. In 1835, however, his tenure was not renewed, largely because he had meanwhile developed into a vociferous abolitionist, considering slavery a betrayal of the promise of the American constitution, and a 'free' America, which he had embraced with great fervour at this arrival in the new world, and on the occasion of his naturalisation. Follen's embrace of the abolitionist cause, his insistence on the equality of black Americans as citizens, must throw a different light on the ethnic aspect of his 'Teutomania'. It would appear to be rooted in his belief in the cultural foundation of enfranchised human collectives, not simply in supremacist racism. 